\title{
Influence of Irrigation Water, Nitrogen and Phosphorus Nutrient Rates on Relative Weight Loss and Sprouting Characteristics of Seed Potato Tubers After Storage
}

\author{
Geofrey K. Gathungu ${ }^{1,2}$, Joseph N. Aguyoh ${ }^{1} \&$ Dorcas K. Isutsa ${ }^{1,2}$ \\ ${ }^{1}$ Department of Crops, Horticulture and Soils, Egerton University, Kenya \\ ${ }^{2}$ Department of Plant Sciences, Chuka University, Kenya \\ Correspondence: Geofrey K. Gathungu, Department of Plant Sciences, Faculty of Agriculture and Environmental \\ Studies, Chuka University, P. O. Box 109-60400, Chuka, Kenya. Tel: 254-722-429-519. E-mail: \\ gkgathungu@yahoo.com
}

Received: June 13, 2013 Accepted: July 15, 2013 Online Published: July 17, 2013

doi:10.5539/sar.v2n4p30

URL: http://dx.doi.org/10.5539/sar.v2n4p30

\begin{abstract}
Potato has overtime generated special importance in most parts of Kenya and the world as a means of strengthening food security and increasing revenue for farmers. However, potato productivity and industry expansion have been constrained by the poor quality seed tubers being produced in the informal seed sector due to inadequate supply of initial planting materials, improper fertilizer management practices and irregular rainfall patterns. A study was done at the Horticultural Research and Teaching Farm of Egerton University to determine the effect of integration of irrigation water, nitrogen and phosphorus rates on seed tuber relative weight loss and sprouting characteristics after storage. The three factors were tested in a split-split plot design where irrigation water supply was assigned to main plots, $\mathrm{N}$ to subplots and $\mathrm{P}$ to sub-subplots. The treatments were replicated three times and the trial repeated once. The treatments consisted of three irrigation water rates $(40 \%, 65 \%$ and $100 \%$ field capacity), applied throughout the potato growth period through drip tube lines. Nitrogen was supplied as urea $(46 \% \mathrm{~N})$ at four equivalent rates of $0,75,112.5$ and $150 \mathrm{~kg} \mathrm{~N} / \mathrm{ha}$, while phosphorus was supplied at planting time as triple superphosphate $\left(46 \% \mathrm{P}_{2} \mathrm{O}_{5}\right)$ at four rates of $0,115,172.5$ and $230 \mathrm{~kg} / \mathrm{ha} \mathrm{P}_{2} \mathrm{O}_{5}$, which translated into $0,50.6,75.9,101.2 \mathrm{~kg}$ P/ha. Data collected included relative percentage weight loss, number of sprouts and sprouting percentage. Data collected was subjected to analysis of variance and significantly different means separated using Tukey's Studentized Range Test at $p \leq 0.05$. The $100 \%$ compared to $65 \%$ and $40 \%$ irrigation water rates resulted in relatively high weight loss, sprout length and reduced the number of sprouts and sprouting percentage of seed tubers. $\mathrm{N}$ and $\mathrm{P}$ rates generally decreased the relative weight loss, improved the number of sprouts and sprouting percentage. It is recommended to apply low to intermediate irrigation water, intermediate to high $\mathrm{N}$ and $\mathrm{P}$ rates to reduce the percentage relative weight loss and sprouting characteristics.
\end{abstract}

Keywords: potato, irrigation water, nitrogen, phosphorus, seed, weight loss, sprouting

\section{Introduction}

Potato has overtime generated special importance in most parts of Kenya and other parts of the world as a means of strengthening food security and increasing revenue for farmers. Potato plays an important role in the Kenyan economy and is currently one of the most important food and cash crops. Potato productivity and industry expansion have been constrained by the poor quality seed tubers being produced in the informal seed sector. Poor seed arise from inadequate supply of initial planting materials, improper fertilizer management practices and irregular rainfall patterns. One of the main constraints is the cost of producing seed tubers since this can account for between $30 \%$ and $50 \%$ of the total production expense depending on the country or region (Correa, et al., 2009). The seed potato tubers must present good physiological characteristics such as minimal weight loss in storage, firmness, total soluble solids content, and sproutability, which are crucial in improving production at the farm level. Poor potato seed tuber quality, irrigation, mineral fertilization, insect pest and disease forecasting, as well as poor planting dates and storage conditions are some of the factors that hinder potato productivity (Walingo et al., 2004).

Potato yield is affected by seed quality characteristics, which include tuber size, shape, wounds, health and 
physiological age (Struik et al., 2006). The purpose of potato storage is to maintain tuber quality and provide a uniform flow of seed tubers to farmers. Seed potato with good storageability should prevent excessive dehydration due to water loss, decay and sprouting. Sprouting, weight loss, rotting and low temperature sweetening are the major problems during storage. The factors contributing to qualitative and quantitative deterioration of potato could be grouped into physical, physiological, microbiological, and entomological factors (Rezaee et al., 2011). The physiological status of seed potato has a great impact on sprouting, and may depend on the water and nutrient management of the crop in the field. Effective sprout control is a major component of managing stored potato quality as sprouting causes increased weight loss resulting in significant reduction of tuber quality (Frazier et al., 2004). Control of seed tuber quality through proper irrigation water and mineral nutrient management is an essential element in the sustainability of the seed industry as it is the basis of increased yield at the farm level.

Conditions under which potatoes are grown including irrigation water and mineral nutrient supply are some of the most important factors affecting seed potato storageability. The physiological status of seed potato after varied irrigation and mineral nutrient supply may affect the quality of the tubers after storage, which may influence the growth and development of resultant potato crop and consequently affecting their productivity. Potato growth depends on a supply of plant nutrients, such as nitrogen $(\mathrm{N})$, phosphorus $(\mathrm{P})$ and potassium $(\mathrm{K})$, each with has a specific function in plant growth and lack of them results in retarded growth processes and reduced yield (Vander Zaag, 1981). Another factor that has limited seed potato production in many parts of Kenya is unreliable rainfall. Potato is sensitive to soil water deficit (Bowen, 2003; Kiziloglu et al., 2006).

Selection of the right potato planting material is one of the most challenging tasks a farmer undertakes to obtain good yields. Small-scale potato farmers are constrained by limited access to both seed potato tuber quantity and quality. Although there exists potential of increasing potato productivity through increased irrigation water, $\mathrm{N}$ and $\mathrm{P}$ application there is limited knowledge on the effects of integrated $\mathrm{N}, \mathrm{P}$ and irrigation rates on seed potato relative weight loss and subsequent sprouting following storage. Knowledge of the effect of integrated water and nutrient management on relative weight loss and sprouting quality of seed potato tubers will help to strengthen the seed potato production system. This study determined the interactive effects of rate of irrigation water, $\mathrm{N}$ and P application on seed potato relative weight loss and sproutability after storage.

\section{Materials and Methods}

\subsection{Potato Growth in the Field}

Potatoes were planted in a rainshelter at the Horticultural Research and Teaching Farm of Egerton University, Njoro between $19^{\text {th }}$ August and $19^{\text {th }}$ December 2011 after which seed potato tubers were stored for 90 days between December 2011 and April 2012 (Trial I). The trial was repeated between $5^{\text {th }}$ April and $6^{\text {th }}$ August 2012 and the seed potato tubers stored for 90 days between August and November 2012 (Trial II).

Potatoes were planted to determine the effect of irrigation water, nitrogen $(\mathrm{N})$ and phosphorus $(\mathrm{P})$ application rates on relative weight loss and tuber sprouting characteristics after 90 days storage. The three factors were tested in a split-split plot design with the irrigation water rate assigned to main plots, $\mathrm{N}$ to subplots and $\mathrm{P}$ to sub-subplots. The treatments were replicated three times. The treatments consisted of three irrigation water (W) rates $(40 \%, 65 \%$ and $100 \%$ field capacity [FC]), applied throughout the potato growth period through drip tube lines. Water was supplied through irrigating only the root zone, leaving the inter-row spaces dry. A WaterScout (Model SM 100 Sensor) connected to 2475 Plant Growth Station (Watch Dog Model, Spectrum Technologies, Plainfield, IL 60585, USA), which is applicable between $0 \%$ to saturation was used to indicate the need for irrigation. Nitrogen $(\mathrm{N})$ was supplied as urea $(46 \% \mathrm{~N})$ at four rates $(0,75,112.5$ and $150 \mathrm{~kg} \mathrm{~N} / \mathrm{ha})$, each in two splits, with the first half at planting and the second at 5 weeks after planting. Phosphorus (P) was supplied at planting time as triple superphosphate $\left(46 \% \mathrm{P}_{2} \mathrm{O}_{5}\right)$ at four rates $\left(0,115,172.5\right.$ and $230 \mathrm{~kg} / \mathrm{ha} \mathrm{P}_{2} \mathrm{O}_{5}$, which translated into 0, 50.6, 75.9, $101.2 \mathrm{~kg}$ P/ha. Each plot measured $1.8 \mathrm{~m} \times 2.25 \mathrm{~m}$. Each experimental unit consisted of seven rows each with seven tubers. Seed potato from 10 randomly selected plants per treatment were harvested 115 days after planting, labelled and placed in plastic bags for testing weight loss and sproutability after storage.

\subsection{Seed Potato Tuber Relative Weight Loss}

The 15 seed potato tubers of seed size I were weighed at the beginning and at the end of the 90 days storage period to determine the absolute tuber weight loss. Relative weight loss (\%) of seed potato after storage was determined by dividing the difference between the initial and final tuber weights after storage by initial weight before storage and multiplying by 100 . 


\subsection{Seed Potato Tuber Sprouting Characteristics}

After 90 days of storage, the number of sprouts and length of longest sprout in three randomly selected tubers per treatment was determined by counting sprouts and measuring with a $30-\mathrm{cm}$ ruler, respectively. The criterion for broken dormancy or sprout development was a stem structure of at least $2 \mathrm{~mm}$ (Van Ittersum, 1992). Sprouting capacity was estimated by expressing the number of developed sprouts as a percentage of total sprouts per tuber.

To be able to determine sprouting per treatment, six samples of seed potato size I, each containing three tubers, were randomly selected every season before planting and the number of eyes counted. During the first season the samples included A $(10,8,9)$, B $(5,7,6), \mathrm{C}(8,6,6), \mathrm{D}(5,7,9), \mathrm{E}(6,5,6), \mathrm{F}(6,6,6)$, whereas season two samples had A1 $(7,5,6), \mathrm{B} 1(6,9,9), \mathrm{C} 1(7,7,8), \mathrm{D} 1(8,7,8), \mathrm{E} 1(6,8,8), \mathrm{F} 2(7,7,9)$; inset being the number of eyes. The data were summed up and used to obtain the average number of eyes. A total of 252 eyes were recorded for the 36 tuber samples.

The average number of eyes in the potato used in the Trial was obtained by dividing the total eyes recorded in both seasons by the number of tubers. This resulted in an average of seven (7) eyes per tuber and was used to determine the percentage sprout per treatment. The percentage sprout was calculated by dividing the sprouts recorded by seven (7) and multiplying by 100 . The vigour was also classified into two categories, according to their length, $<1 \mathrm{~cm}$ (weak) and $>1 \mathrm{~cm}$ (strong) (Van Ittersum, 1992).

\subsection{Data Analysis}

Data collected were subjected to analysis of variance using the SAS system for windows V8 1999-2001 by SAS Institute Inc., Cary, NC, USA and significantly different means separated using Tukey's Studentized Range Test at $\mathrm{p} \leq 0.05$

\section{Results}

\subsection{Seed Potato Tuber Relative Weight Loss}

The relative weight loss (\%) of seed potato at 90 days after storage (90 DAS) significantly depended on irrigation water, $\mathrm{N}$ and $\mathrm{P}$ rates. Integration of irrigation water with either $\mathrm{N}$ or $\mathrm{P}$ also significantly influenced the percentage relative weight loss of the seed potato tubers. Slight differences were also observed from combination of $\mathrm{N}$ and $\mathrm{P}$ rates both in Trials I and II (Table 1).

Low irrigation water rate at $40 \%$ decreased the relative weight loss of seed potato tubers in storage. A lower relative weight loss was observed with low irrigation water rate at $40 \%$ compared to $65 \%$ and $100 \%$. A relative weight loss of $12.37 \%$ and $10.51 \%$ was observed with high compared with $7.51 \%$ and $5.87 \%$ recorded with low irrigation water rate both in Trials I and II, respectively. The $100 \%$ compared to $40 \%$ irrigation water rate together with low $\mathrm{N}$ rate of $0 \mathrm{~kg} \mathrm{~N} / \mathrm{ha}$ increased the relative weight loss in seed potato tubers at 90 DAS. Nitrogen decreased the relative weight loss of seed potato tubers regardless of the irrigation water rate (Table 1).

Weight loss decreased from $12.37 \%$ and $10.51 \%$ with low $\mathrm{N}$ rate of $0 \mathrm{~kg} \mathrm{~N} / \mathrm{ha}$ to $9.90 \%$ and $7.82 \%$ with high $\mathrm{N}$ rate of $150 \mathrm{~kg} \mathrm{~N} / \mathrm{ha}$, when supplied with $100 \%$ irrigation water rate in Trials I and II, respectively. With low irrigation water rate, weight loss reduced from $7.51 \%$ and $5.87 \%$ to $7.11 \%$ and $5.44 \%$ both with the low and high $\mathrm{N}$ rates of 0 and $150 \mathrm{~kg} \mathrm{~N} / \mathrm{ha}$, respectively. Greater reduction in weight loss resulted with high compared to low irrigation water rate when high $\mathrm{N}$ rate of $150 \mathrm{~kg} \mathrm{~N} / \mathrm{ha}$ was supplied. However, significant decrease in weight loss was only evident where high irrigation water rate was supplied. Application of high $\mathrm{N}$ rate did not significantly decrease the relative weight loss of seed potato tubers where $40 \%$ and $65 \%$ irrigation water rates were supplied (Table 1). 
Table 1. Effect of irrigation water, $\mathrm{N}$ and $\mathrm{P}$ application rates on percentage weight loss of seed potato at $90 \mathrm{DAS}$

\begin{tabular}{|c|c|c|c|c|c|c|c|c|c|c|c|}
\hline \multirow{2}{*}{ Trial I } & & \multicolumn{5}{|c|}{$\mathrm{N}$ rate $(\mathrm{kg} \mathrm{N} / \mathrm{ha})$} & \multicolumn{5}{|c|}{$\mathrm{P}$ rate $(\mathrm{kg} \mathrm{P} / \mathrm{ha})$} \\
\hline & & 0 & 75 & 112.5 & 150 & Mean & 0 & 50.6 & 75.9 & 101.2 & Mean \\
\hline \multirow{3}{*}{ 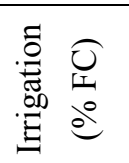 } & 100 & $12.37 \mathrm{a}^{*}$ & $11.26 \mathrm{ab}$ & $10.73 b c$ & $9.90 \mathrm{c}$ & 11.06 & $12.66 \mathrm{a}$ & $11.15 b$ & $10.63 \mathrm{c}$ & $9.81 \mathrm{~d}$ & 11.07 \\
\hline & 65 & $9.34 \mathrm{a}$ & $9.19 \mathrm{a}$ & $8.80 \mathrm{a}$ & $8.65 \mathrm{a}$ & 8.99 & $9.36 \mathrm{a}$ & $8.91 b$ & $8.90 \mathrm{~b}$ & $8.82 b$ & 8.99 \\
\hline & 40 & $7.51 \mathrm{a}$ & $7.36 \mathrm{a}$ & $7.11 \mathrm{a}$ & $7.11 \mathrm{a}$ & 7.27 & $7.60 \mathrm{a}$ & $7.40 \mathrm{a}$ & $7.11 \mathrm{~b}$ & $6.97 b$ & 7.27 \\
\hline \multicolumn{2}{|l|}{ Mean } & 9.74 & 9.27 & 8.88 & 8.55 & & 9.88 & 9.15 & 8.88 & 8.53 & \\
\hline \multicolumn{2}{|l|}{$\operatorname{MSD}(\mathrm{N})$} & 1.36 & & & & & & & & & \\
\hline \multicolumn{2}{|l|}{$\operatorname{MSD}(\mathrm{P})$} & 0.45 & & & & & & & & & \\
\hline \multicolumn{2}{|l|}{$\operatorname{MSD}(\mathrm{W})$} & 1.05 & & & & & & & & & \\
\hline \multicolumn{2}{|l|}{$\mathrm{CV}(\%)$} & 3.73 & & & & & & & & & \\
\hline \multicolumn{12}{|l|}{ Trial II } \\
\hline \multirow{3}{*}{ 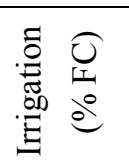 } & 100 & $10.51 \mathrm{a}$ & $9.29 \mathrm{ab}$ & $8.65 b c$ & $7.82 \mathrm{c}$ & 9.07 & $11.06 \mathrm{a}$ & $9.11 b$ & $8.26 \mathrm{c}$ & $7.85 \mathrm{c}$ & 9.07 \\
\hline & 65 & $7.27 \mathrm{a}$ & $6.81 \mathrm{a}$ & $6.46 a$ & $6.41 \mathrm{a}$ & 6.74 & $7.46 \mathrm{a}$ & $6.81 \mathrm{~b}$ & $6.57 b$ & $6.10 \mathrm{c}$ & 6.74 \\
\hline & 40 & $5.87 \mathrm{a}$ & $5.63 a$ & $5.49 \mathrm{a}$ & $5.44 \mathrm{a}$ & 5.61 & $6.81 \mathrm{a}$ & $5.26 b$ & $5.23 b$ & $5.13 b$ & 5.61 \\
\hline \multicolumn{2}{|l|}{ Mean } & 7.88 & 7.24 & 6.87 & 6.56 & & 8.44 & 7.06 & 6.69 & 6.36 & \\
\hline \multicolumn{2}{|l|}{$\operatorname{MSD}(\mathrm{N})$} & 1.42 & & & & & & & & & \\
\hline \multicolumn{2}{|l|}{$\operatorname{MSD}(\mathrm{P})$} & 0.48 & & & & & & & & & \\
\hline \multicolumn{2}{|c|}{ MSD (W) } & 1.09 & & & & & & & & & \\
\hline \multicolumn{2}{|l|}{$\mathrm{CV}(\%)$} & 5.90 & & & & & & & & & \\
\hline
\end{tabular}

* Means followed by the same letter(s) along the row for $\mathrm{N}$ and $\mathrm{P}$ rates by irrigation water rate are not significantly different at $\mathrm{p} \leq 0.05$ according to Tukey's Studentized Range Test. MSD $=$ Minimum Significant Difference.

Similarly, P application decreased the relative weight loss of seed tubers regardless of the irrigation water rate. The relative weight loss of seed tubers decreased with increases in P rate. However, significant differences between the $\mathrm{P}$ rates were only evident with $100 \%$ irrigation water rate. With $40 \%$ and $65 \%$ irrigation water rates, significant decrease was only evident up to $50.6 \mathrm{~kg}$ P/ha after which high rate of P up to 75.9 and $101.2 \mathrm{~kg} \mathrm{P} / \mathrm{ha}$ did not significantly decrease the relative weight loss of seed potato tubers. Like $\mathrm{N}$ application, greater reduction in relative weight loss was observed when high $P$ was combined with high irrigation water rate (Table 1).

\subsection{Seed Potato Tuber Sprouting Characteristics}

After 90 days of storage, the sprouting capacity of seed potato tubers which was expressed as a percentage significantly depended on the individual effects of irrigation water, $\mathrm{N}$ and $\mathrm{P}$ application rates and it was not affected by their combinations. The sprout length other than being significantly dependent on irrigation, $\mathrm{N}$ and $\mathrm{P}$ application rates was also affected by the integration of irrigation water rate and $\mathrm{P}$ application (Table 2).

Irrigation water rate significantly decreased the number of sprouts and percentage sprouting. High irrigation rate at $100 \%$ reduced the number of sprouts to 3.77 and 4.65 compared to intermediate irrigation water rate at $65 \%$, which increased them to 4.71 and 5.71 in Trials I and II, respectively. Irrigation water rate at $100 \%$ had $58.87 \%$ and $66.37 \%$ sprouting compared to intermediate irrigation water rate at $65 \%$, which had $67.26 \%$ and $81.55 \%$ sprouting in Trials I and II, respectively. Compared to irrigation water rate, $\mathrm{N}$ application significantly increased the number of sprouts and the percentage sprouting of seed potato tubers (Table 2).

Application of $\mathrm{N}$ from 0 to $150 \mathrm{~kg} \mathrm{~N} / \mathrm{ha}$ significantly increased the number of sprouts from 3.83 and 4.64 to 4.81 and 5.5, and sprouting from $54.76 \%$ and $66.27 \%$ to $68.65 \%$ and $78.57 \%$ in Trials I and II, respectively. However, non-significant increases were observed between 0 and $75 \mathrm{~kg} \mathrm{~N} / \mathrm{ha}$, and between 112.5 and $150 \mathrm{~kg} \mathrm{~N} / \mathrm{ha}$ in both Trials. Increase of P rate from 0 to $101.2 \mathrm{~kg} \mathrm{P} / \mathrm{ha}$ also significantly increased the number of sprouts and the percentage sprouting of seed potato tubers. The number of sprouts increased from 3.75 and 4.53 to 4.75 and 5.69 , and sprouting from $53.57 \%$ and $64.68 \%$ to $67.86 \%$ and $81.35 \%$ with 0 and $101.2 \mathrm{~kg} \mathrm{P} / \mathrm{ha}$ in both Trials (Table 2). 
Comparatively, higher sprout numbers and a better percentage sprouting were observed in Trial II compared to Trial I, regardless of irrigation, $\mathrm{N}$ and $\mathrm{P}$ rates (Table 2).

Table 2. Effect of irrigation water, $\mathrm{N}$ and $\mathrm{P}$ application rates on seed potato sprouts and percentage sprouting

\begin{tabular}{|c|c|c|c|c|}
\hline \multirow[b]{2}{*}{ Irrigation water rate $(\% \mathrm{FC})$} & \multicolumn{2}{|c|}{ Number of sprouts } & \multicolumn{2}{|c|}{ Percentage sprouting } \\
\hline & Trial I & Trial II & Trial I & Trial II \\
\hline 100 & $3.77 \mathrm{a}^{*}$ & $4.65 \mathrm{a}$ & $53.87 \mathrm{a}$ & $66.37 \mathrm{a}$ \\
\hline 65 & $4.71 \mathrm{c}$ & $5.71 \mathrm{c}$ & $67.26 \mathrm{c}$ & $81.55 \mathrm{c}$ \\
\hline 40 & $4.29 b$ & $5.06 \mathrm{~b}$ & $61.31 \mathrm{~b}$ & $72.32 b$ \\
\hline $\operatorname{MSD}(\mathrm{W})$ & 0.20 & 0.21 & 2.85 & 2.97 \\
\hline \multicolumn{5}{|l|}{$\mathrm{N}$ rate $(\mathrm{kg} / \mathrm{ha})$} \\
\hline 0 & $3.83 \mathrm{a}$ & $4.64 \mathrm{a}$ & $54.76 \mathrm{a}$ & $66.27 \mathrm{a}$ \\
\hline 75 & $4.06 \mathrm{a}$ & $5.06 \mathrm{~b}$ & $57.94 \mathrm{a}$ & $72.22 b$ \\
\hline 112.5 & $4.33 b$ & $5.36 \mathrm{c}$ & $61.90 \mathrm{~b}$ & $76.59 \mathrm{c}$ \\
\hline 150 & $4.81 \mathrm{c}$ & $5.50 \mathrm{c}$ & $68.65 \mathrm{c}$ & $78.57 \mathrm{c}$ \\
\hline $\operatorname{MSD}(\mathrm{N})$ & 0.25 & 0.26 & 3.62 & 3.76 \\
\hline \multicolumn{5}{|l|}{ P rate $(\mathrm{kg} / \mathrm{ha})$} \\
\hline 0 & $3.75 \mathrm{a}$ & $4.53 \mathrm{a}$ & $53.57 \mathrm{a}$ & $64.68 \mathrm{a}$ \\
\hline 50.6 & $4.05 \mathrm{~b}$ & $5.00 \mathrm{~b}$ & $58.33 b$ & $71.43 b$ \\
\hline 75.9 & $4.44 \mathrm{c}$ & $5.33 \mathrm{c}$ & $63.49 \mathrm{c}$ & $76.19 \mathrm{c}$ \\
\hline 101.2 & $4.75 \mathrm{~d}$ & $5.69 \mathrm{~d}$ & $67.86 \mathrm{~d}$ & $81.35 \mathrm{~d}$ \\
\hline $\operatorname{MSD}(\mathrm{P})$ & 0.25 & 0.26 & 3.62 & 3.76 \\
\hline CV (\%) & 9.59 & 8.27 & 9.59 & 8.27 \\
\hline
\end{tabular}

* Means followed by the same letter(s) along the column for irrigation water, $\mathrm{N}$ and $\mathrm{P}$ rates are not significantly different at $\mathrm{p} \leq 0.05$ according to Tukey's Studentized Range Test. Interactions are not significantly different at $\mathrm{p}$ $\leq 0.05$. MSD $=$ Minimum Significant Difference.

Increasing $\mathrm{N}$ rate from 0 to $150 \mathrm{~kg} \mathrm{~N} /$ ha significantly increased the seed potato sprout length from 7.83 and 3.17 $\mathrm{cm}$ with $0 \mathrm{~kg} \mathrm{~N} / \mathrm{ha}$ to 12.0 and $5.63 \mathrm{~cm}$ with high $\mathrm{N}$ rate at $150 \mathrm{~kg} \mathrm{~N} / \mathrm{ha}$ in both Trials (Figure 1). However, higher sprout length was observed in Trial I compared to Trial II regardless of irrigation, $\mathrm{N}$ or P rates. Overall, lower number of sprouts and percentage sprouting were observed with high irrigation water rate when coupled with lower rates of both $\mathrm{N}$ and $\mathrm{P}$ in both Trials I and II, respectively $(\mathrm{p} \leq 0.05)$.

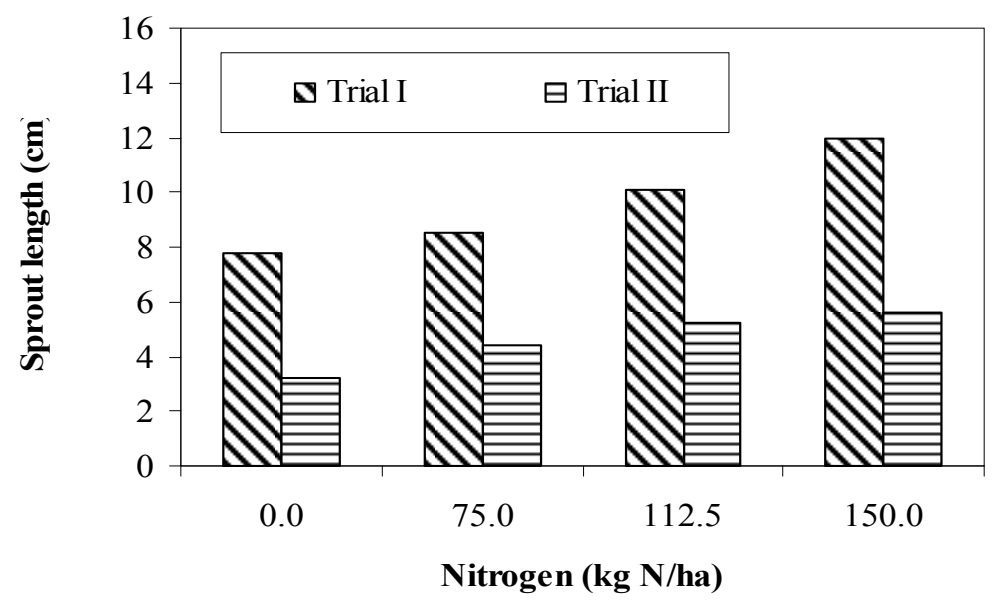

Figure 1. Effect of nitrogen rate on seed potato sprout length 
The sprout length at 90 DAS also significantly depended on irrigation water and $\mathrm{P}$ rates. Low irrigation water rate at $40 \%$ together with low $\mathrm{P}$ rate of $0 \mathrm{~kg}$ P/ha reduced the sprout length to 4.7 and $3.2 \mathrm{~cm}$ compared to 9.85 and $4.13 \mathrm{~cm}$ recorded for high irrigation water rate of $100 \%$ with the same $\mathrm{P}$ rate of $0 \mathrm{~kg} \mathrm{P} / \mathrm{ha}$ in both Trials. However, application of high $\mathrm{P}$ rate at $101.2 \mathrm{~kg} \mathrm{P} / \mathrm{ha}$ significantly increased the sprout length to 8.9 and $4.4 \mathrm{~cm}$ with $40 \%$ irrigation water rate compared to 16.18 and $7.38 \mathrm{~cm}$ observed with $100 \%$ irrigation water rate in both Trials. Low compared to high irrigation water rate decreased the sprout length, whereas higher rates of $\mathrm{P}$ increased the sprout length (Table 3).

Table 3. Effect of irrigation water and $\mathrm{P}$ application rates on seed potato sprout length

\begin{tabular}{lllllllllll}
\hline & \multicolumn{3}{l}{ P rate (kg P/ha) in Trial I } & \multicolumn{6}{c}{ P rate (kg P/ha) in Trial II } \\
\hline Irrigation water (\% FC) & 0 & 50.6 & 75.9 & 101.2 & Mean & 0 & 50.6 & 75.9 & 101.2 & Mean \\
100 & $9.85 \mathrm{a}^{*}$ & $11.19 \mathrm{~b}$ & $13.64 \mathrm{c}$ & $16.18 \mathrm{~d}$ & 12.72 & $4.13 \mathrm{a}$ & $5.12 \mathrm{~b}$ & $5.59 \mathrm{c}$ & $7.38 \mathrm{~d}$ & 5.56 \\
65 & $7.01 \mathrm{a}$ & $8.13 \mathrm{~b}$ & $9.99 \mathrm{c}$ & $12.93 \mathrm{~d}$ & 9.52 & $3.23 \mathrm{a}$ & $4.05 \mathrm{~b}$ & $4.84 \mathrm{c}$ & $5.48 \mathrm{~d}$ & 4.4 \\
40 & $4.7 \mathrm{a}$ & $5.23 \mathrm{a}$ & $7.54 \mathrm{~b}$ & $8.9 \mathrm{c}$ & 6.59 & $3.2 \mathrm{a}$ & $3.68 \mathrm{~b}$ & $3.99 \mathrm{bc}$ & $4.4 \mathrm{c}$ & 3.82 \\
Mean & 7.19 & 8.18 & 10.39 & 12.67 & & 3.52 & 4.28 & 4.81 & 5.75 & \\
MSD (P) & 0.72 & & & & & 0.44 & & & & \\
MSD (W) & 0.57 & & & & & 0.35 & & & & \\
CV (\%) & 9.61 & & & & & 4.59 & & & & \\
\hline
\end{tabular}

* Means followed by the same letter(s) along the row for irrigation water by P rates are not significantly different at $\mathrm{p} \leq 0.05$ according to Tukey's Studentized Range Test. MSD $=$ Minimum Significant Difference.

\section{Discussion}

In Kenya, farmers grow seed potato during the rainy season using fertiliser rates of commercial potato production. In this study, 100\% irrigation water rate represented a normal rainy season, and fertiliser rates were varied from zero to commercial potato production rates. Reduction in seed potato weight after storage can be an indication of deterioration of seed potato quality and was found to depend on potato growing conditions tested in this study. The seed potato tuber relative weight loss decreased with increase in irrigation water rate, and increased with increased in $\mathrm{N}$ and $\mathrm{P}$ application rates. The seed potato tubers from high compared to lowest and intermediate irrigation water rates had the greatest relative weight loss after storage. Chachin and Iwata (1981) reported that weight loss in stored potato may be due to higher respiration rate, increased membrane permeability and more sprout development. This probably suggests that potato supplied with high irrigation water rate absorbed more of it into the seed tubers which lead to more water being available for physiological processes such as transpiration and respiration within the seed and also promoted sprouting. This consequently, resulted to a greater weight loss. Sprouting has been reported to cause increased weight loss and is also associated with the conversion of starch to sugars (Frazier et al., 2004). This then suggests that the seed potato harvested from plants grown with low irrigation water rate were in a relatively inactive physiological state during storage compared to those harvested from plants supplied with high irrigation water rate, which were probably characterized by high metabolic activities. The seed water content has been reported to affect the rate of metabolic and deteriorative reactions (Vertucci \& Roos, 1990).

Neubauer et al. (1967) reported that weight loss in storage resulted primarily due to evaporation of water. In this study seed tuber weight at 90 DAS was less than at harvest. This continued throughout the storage period due to a net loss of seed moisture (desorption) to the environment. Asomaning (2011) indicated that all seeds are hygroscopic and automatically absorb or desorb moisture by diffusion along a water potential gradient between the seed and the surrounding air. This suggests that when seed potato tubers from high irrigation water rates were placed in storage they lost moisture to the environment due to high initial moisture content and consequently decreased in weight. However, greater loss in weight was observed with potato supplied with high compared to low irrigation water rate, especially when low $\mathrm{N}$ and $\mathrm{P}$ rates were applied. Probably high $\mathrm{N}$ and $\mathrm{P}$ rates assisted in binding water molecules within the seed potato resulting in low evaporation. This may explain why irrigation water rate treatments with low compared to high rates of $\mathrm{N}$ and $\mathrm{P}$ experienced high relative water loss.

The seed potato tubers from low or intermediate irrigation, high $\mathrm{N}$ and $\mathrm{P}$ rates had high starch and dry matter 
content. Gold and Hay (2008) reported that the dry matter in starchy seeds attracts and holds water molecules. This probably explains why the seed potato tubers grown under both high irrigation, low $\mathrm{N}$ and $\mathrm{P}$ rates experienced greater weight loss at 90 DAS due to low dry matter and starch contents. The weight loss could also be contributed to physiological aging of tubers and water loss as seed potato equilibrates or maintains at a specific moisture level. Loss of moisture as observed with 100\% irrigation water rate has been reported to lead to quality loss and finally to non-marketable produce (Kibar, 2012). When low to intermediate irrigation, high $\mathrm{N}$ and $\mathrm{P}$ rates were applied minimal weight loss was observed in storage. Probably $\mathrm{N}$ and $\mathrm{P}$ application improved the strength and integrity of seed potato membrane, and minimized the metabolic and deteriorative reactions that lead to weight loss.

The number of sprouts and sprouting percentage decreased with increase in irrigation water rate and increase in $\mathrm{N}$ and $\mathrm{P}$ rates. However, the sprout lengths were much longer with the $100 \%$ irrigation water rate, and the number of short sprouts was greater in the seed potato tubers grown under low irrigation water rate. Neubauer et al. (1967) reported that when seed potato were stored under different relative humidity environments, dry potatoes grew the most numerous short sprouts, while the humidified tubers grew much longer and fewer sprouts.

Potatoes supplied with low irrigation water rate attained physiological maturity earlier and therefore their seed tubers were physiologically older than those from plants supplied with high irrigation water rate. However, though these seed potatoes from low irrigation water rate attained physiological maturity earlier, probably they contained less moisture content, and therefore were physiologically inactive in storage, resulting in late germination that led to less sprout length. The high moisture content in the seed potato tubers obtained from high irrigation water rate might have stimulated their enzymatic activity, enhancing rapid germination of the eyes, which shortened the sprouting period. The high moisture facilitated physiological processes leading to earlier sprouting and consequently produced longer, but fewer sprouts. The stimulated sprouting in the seed potato obtained from high irrigation water rate could have had a negative influence on the tubers as they lost energy, moisture and withered due to the high respiration.

The potato plants supplied with high irrigation water rate had high growth and development, which could have resulted in less of the photoassimilates being deposited in the tubers. Consequently, these seed potato tubers had low TSS content, which could not have sustained more sprouts. The low TSS possibly resulted in fewer, but longer sprouts. The longer sprouts were primarily due to earlier germination. However, longer sprouts are tender and susceptible to mechanical damage. Due to the balanced growth and development of potatoes supplied with intermediate irrigation water rate, their seed tubers had average moisture content and TSS accumulation, which resulted in high number of sprouts, sprouting percentage and sprout length. Though the potatoes supplied with low irrigation water rate resulted in seed tubers with high TSS content, probably the slightly low moisture content within the seed tubers could not have resulted in their better performance as those grown under intermediate irrigation water rate.

Sprouting is the development of shoots in potatoes and each seed potato tuber has from two to as many as 10 buds or "eyes". The eyes generate shoots that grow into new plants under favourable conditions. Sprouting of shoots from tuber "eyes" starts at the end of the dormancy period (Junkeviciene et al., 2011). It is possible that seed potato produced using high irrigation water rate had their natural dormancy broken earlier, and were actively converting their starch into sugar and other nutrients needed for sprout germination and growth and hence resulted in greater sprout length. Fresh potato tubers are in a state of endogenous dormancy, which must be terminated before sprout growth commences (Kandil et al., 2012) and remain dormant for up to 10 weeks, depending on the variety and seasonal weather conditions during the growth period (Kurzinger, 2007). Therefore, tuber sprouting during storage results after cessation of natural dormancy of the tuber. Sanli et al. (2010) reported that potato tubers start sprouting when dormancy is broken and sprout lengths continue to increase as long as they can obtain nutrients from tubers. The amount of moisture and TSS within the seed potato tuber as a result of different irrigation water rate probably influenced the seed potato quality, including the physiological processes, which led to differences in sprouting characteristics.

\section{Conclusion}

It is possible that potatoes supplied with high irrigation, low $\mathrm{N}$ and $\mathrm{P}$ rates were physiologically disadvantaged, which impacted on their quality and consequently experienced reduced sprouting. Seed growing conditions of different irrigation, $\mathrm{N}$ and $\mathrm{P}$ application rates had an impact on the seed physiological age, which led to varied relative water loss and sprouting characteristics. In general, the most effective treatments to reduce weight loss of tubers and increase sprouting characteristics were integration of low to intermediate irrigation water rate with 
high $\mathrm{N}$ and $\mathrm{P}$ rates. Farmers in the informal sector should, therefore, be made aware of these optimal conditions, under which to grow potatoes destined for use as seed.

\section{Acknowledgements}

The authors acknowledge the support given by National Commission for Science, Technology and Innovation in funding this study, and Egerton University for logistical support.

\section{References}

Asomaning, J. M., Sacande, M., \& Olympio, N. S. (2011). Water sorption isotherm characteristics of seeds of six indigenous forest tree species in Ghana. West African Journal of Applied Ecology, 18, 15-28. Retrieved from http://www.ajol.info/index.php/wajae/article/view/70312/58548

Bowen, W. T. (2003). Water productivity and potato cultivation. In J. W. Kijne, R. Barker \& D. Molden (Eds.), Water Productivity in Agriculture: Limits and Opportunities for Improvement (pp. 229-238). CAB International, Wallingford, UK. http://dx.doi.org/10.1079/9780851996691.0229

Chachin, K., \& Iwata, T. (1981). Respiratory metabolism and potassium release of irradiated potatoes. In Seminar on Food Irradiation for Developing Countries in Asia and the Pacific held in November in Tokyo, Japan. Paper No. IAEA-SR-60/15. p. 131.

Correa, R. M., Pinto, J. E. B. P., Faquin, V., Pinto, C. A. B. P., \& Reis, E. S. (2009). The production of seed potatoes by hydroponic methods in Brazil. Fruit, Vegetable and Cereal Science and Biotechnology, 3(1), 133-139. Retrieved from http://nhjy.hzau.edu.cn/kech/ssyy/qysd/wtzp/5.pdf

Frazier, M. J., Olsen, N., \& Kleinkopf, G. (2004). Organic and alternative methods for potato sprout control in storage. University of Idaho Extension, Idaho Agricultural Experiment Station, Moscow, Idaho, USA. Retrieved

from http://idahodocs.contentdm.oclc.org/cdm/compoundobject/collection/p15100coll7/id/2027/rec/4

Gold, K., \& Hay, F. (2008). Equilibrating seeds to specific moisture levels. Technical Information Sheet 09. Millennium Seed Bank Project, Wakehurst Place Ardingly, West Sussex, UK. Retrieved from http://www.kew.org/ucm/groups/public/documents/document/ppcont_014353.pdf

Jukneviciene, Z., Venskutonience, E., Pranaitiene, R., \& Duchovskis, P. (2011). The influence of different temperatures and exposition time on potato tuber sprouting and development of plants. Zemdirbyste (Agriculture), $98(2), \quad$ 131-138. $\quad$ Retrieved from http://www.lzi.lt/tomai/98\%282\%29tomas/98_2_tomas_str3.pdf

Kandil, A. A., Sharief, A. E., \& Abd El-Atif, A. M. Y. (2012). Encouragement germination of potato seed cultivars (Solanum tuberosum L.). J. Basic \& Applied Sci, 8, 223-230. Retrieved from http://www.lifescienceglobal.com/images/Journal_articles/JBASV8N1A34-Sharief.pdf

Kibar, H. (2012). Design and management of postharvest potato (Solanum tuberosum L.) storage structures. Ordu Univ. J. Sci. Tech., 2(1), 23-48. Retrieved from http://btd.odu.edu.tr/files/cilt2/makale_3.pdf

Kiziloglu, F. M., Sahin, U., Tune, T., \& Diler, S. (2006). The effect of deficit irrigation on potato evapotranspiration and tuber yield under cool season and semiarid climatic conditions. J. Agron., 5, 284-288. http://dx.doi.org/10.3923/ja.2006.284.288

Kurzinger, S. L. (2007). Germination inhibition for quality assurance for table potatoes, refinement potatoes and also seed potatoes. Landesforschungsanstalt Gulzow, MV, Germany. Kartoffelbau, 8, 308-13.

Neubauer, L. W., Puri, Y. P., \& Kucera, E. R. (1967). Effects of relative humidity on Irish potatoes in storage. University of California Tulelake Field Station, Siskiyou County, California Agriculture, November, pp. 4-5. http://ucce.ucdavis.edu/files/repositoryfiles/ca2111p4-64376.pdf

Rezaee, M., Almassi, M., Majdabadi, F. A., Minaei, S., \& Khodadadi, M. (2011). Potato sprout inhibition and tuber quality after post harvest treatment with gamma irradiation on different dates. J. Agr. Sci. Tech., 13, 829-842. Retrieved from http://jast.journals.modares.ac.ir/?_action=articleInfo\&article=449

Sanli, A., Karadogon, T., Tonguc, M., \& Baydar, H. (2010). Effects of caraway (Carum carvi L.) Seed on Sprouting of Potato (Solanum tuberosum L.) tubers under different temperature conditions. Turkish Journal of Field Crops, 15(1), 54-58. Retrieved from http://tarlabitkileridernegi.org/issues/2010-15n1/12.pdf 
Struik, P. C., van der Putten, P. E. L., Caldiz, D. O., \& Scholte, K. (2006). Response of stored potato seed tubers from contrasting cultivars to accumulated day-degrees. Crop Science, 46, 1156-1168. http://dx.doi.org/10.2135/cropsci2005.08-0267

Van Ittersum, M. K. (1992). Dormancy and growth vigour of seed potatoes. Ph.D. Thesis. Wageningen University, Wageningen, The Netherlands, p. $187 . \quad$ Retrieved from http://library.wur.nl/WebQuery/clc/568915

Vertucci, C. W., \& Roos, E. E. (1990). Theoretical basis of protocols for seed storage. Plant Physiol., 94, 1019-1023. http://dx.doi.org/10.1104/pp.94.3.1019

Walingo, A., Lung'aho, C., Ng'ang'a, N., Kinyae, P. M., \& Kabira, J. N. (2004). Potato marketing, storage, processing and utilization in Kenya. In A. Hanafi (Ed.), Proceeding of Sixth Triennial Congress of the African Potato Association held at Agadir Morocco from 5-10 April 2004.

\section{Copyrights}

Copyright for this article is retained by the author(s), with first publication rights granted to the journal.

This is an open-access article distributed under the terms and conditions of the Creative Commons Attribution license (http://creativecommons.org/licenses/by/3.0/). 